ya que sobre su miseria y su atraso se levanta el poderío de los estados iniperialistas.

Un nacionalismo consciente no supone, como afirman y propagan de otro lado los vagos radicalistas, el odio ciego y unilateral por los países considerados dentro del radio imperialista. El moderno concepto de nacionalismo no está hecho en la medida estrecha de los regionalismos medioevales, y está exclusivamente dirigido contra la casta plutocrática que desde el poder del Estado o desde la banca-otra forma del mismo poder-, dirigen su explotación sobre los pueblos coloniales. No está incluida, como es lógico, la otra clase social que en los países imperialistas contribuye con su fuerza y trabajo a la consolidación de la casta explotadora. Y sí incluye a los del propio país colonial que se alían con los imperialistas para permitirle la libre entrada y la libre explotación de las grandes masas de trabajadores de la ciudad y del campo.

$\mathrm{Y}$ en su concepto constructivo, un nacionalismo lleva la finalidad de unificar todas las fuerzas nacionales para llevar a los pueblos a un verdadero progreso, libre de influencias extrañas y de tutelajes interesados.

Los Estados Unidos de Europa, fórmula de peligro para la defensa del poder económico del viejo continente, amenazado por el imperialismo yanqui, es un ejemplo magnífico que nuestros maestros de siempre nos ofrecen y que lleva en sí el secreto de nuestra prosperidad futura. ¿Con la inconsciencia de la irresponsabilidad dejaremos para cuando el remedio sea inútil la formación de una Federación de Estados Latino-americanos, como lo previó el Libertador, única valla para contener apetitos?-M A G D P O R T A L.

\title{
Precursores, profetas y salvadores
}

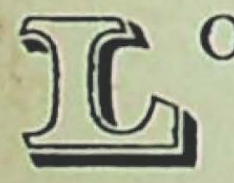

OS trastornos sociales y políticos que sufre el mundo en la actualidad son considerados generalmente como una consecuencia de la gran guerra. Pero bien miradas las cosas, es posible advertir que, tanto ésta como el estado caótico que constituye su ineludible derivado, no hubieran sido posibles si el incremento del progreso material y la vertiginosa velocidad que en este siglo ha adquirido la vida no hubieran predispuesto el ánimo al cataclismo, multiplicando las dificultades de la lucha por la existencia, haciendo más en- 
carnizadas las competencias y desarrollando el egoísmo del hombre, que se materializa en razón directa del bienestar que adquiere.

Así lo que está al margen de la lógica no es este estado de crisis permanente, sino la solución que se pretende darle. De acuerdo con un criterio sano y normal, debieran realizarse estudios aislados por especialistas en economía, por filósofos, capitalistas y trabajadores, correspondiendo al político la tarea de una sabia coordinación. Pero, por desgracia, nuestra propia desorientación nos ha llevado a querer descubrir la panacea universal y cada cual pretende asumir un rol mesiánico y a ofrecer el compendio de la sabiduría y el bien.

Mientras en la industria y el comercio se nota una marcada tendencia a la especialización, en lo intelectual se aspira a un peligroso universalismo. Nadie se conforma con ser únicamente lo que es; nadie se circunscribe a su propia tarea; nadie permanece tranquilo, en actitud de estudioso, dentro del modesto laboratorio. La publicidad ha alcanzado un desmedido etxremo, no en lo concerniente a la indispensable réclame comercial, sino en lo relativo a la figuración vanidosa e inútil. Los autores no se contentan con subrayar sus condiciones intelectuales, sino que diariamente se desnudan en un escaparate, frente al público, y pretenden alcanzar mayor renombre opinando sobre toda clase de asuntos, mostrando las insignificancias de su vida íntima, en un afán de actualidad constante, como si exponiéndose a la consideración de las gentes, en perpetua pose, hallaran mayores facilidades para alcanzar el éxito. Los autores no se contentan con el renombre literario; acaso al presenciar las turbulencias y trastornos de la hora presente, recuerdan el viejo refrán a río revuelto, ganancia de pescadores, con la secreta esperanza de no ser ellos los peces.

$\mathrm{El}$ arte por el arte casi ha desaparecido, cediendo lugar a una literatura tendenciosa. Actualmente hay quienes afirman que el escritor ha de relacionarse e inmiscuirse en los problemas que inquietan la conciencia del mundo, correspondiéndole, en relación a ellos, la triple misión del precursor, el profeta y el salvador. Este género de literatura tendenciosa se ejercita en dos formas diversas. La una, que no constituye propiamente una literatura sino que significa más bien una estúpida alharaca demagógica, derivada de la actualidad política o social de un personaje. Se da, por ejemplo, el caso de un obrero revolucionario que aspira a trascender intelectualmente. Un señor Gorkin, verbi-gracia, proletario español, eterno huelguista perseguido por los patrones y el Gobierno, que amparado por 
Barbusse pretende aprovechar la simpatía que despiertan su condición de víctima y sus deseos de ilustrarse para lograr renombre en el mundo de las letras, sin conseguirlo ciertamente por falta de personalidad, de sensibilidad y buen gusto. Sus libros no son más que torpes alegatos de mitin público, en los que a cada paso se pretende presentar como novedades observaciones, sentimientos y autores que la gente instruida ha descubierto desde hace mucho tiempo. El mismo caso se produce a la inversa entre los señores que en otra época alcanzaron situación expectable en la política y que hoy nos amenazan con toda suerte de Memorias, Diarios íntimos y otras audacias literarias. Es lo que sucede con el Conde de Romanones, con sus Notas de una vida y su biografía de Sagasta.

Pero la segunda y más peligrosa forma de esta literatura tendenciosa se traduce en el afán con que muchos escritores consagrados quieren aprovechar su prestigio literario para transformarse en caudillos y erigir cátedra magistral. Tolstoy, con su snobismo demócrata y su cloctrina confusa, es el tipo representativo de esta escuela, pero existen para él las atenuantes de haber vivido en Rusia y en pleno siglo XIX. En cambio, para Romain Rolland y para Istrati no creo que haya perdón en esta época de realidades, de concreciones y de urgencias.

En esto no podemos ver más que un signo de evidente decaimiento. Cuando el escritor sin talento, o el que siente aminorar su potencia intelectual, tiende a convencerse a sí mismo y procura convencer a los demás de que escribir no es tener ideas, imágenes, gracia, amenidad, etc., sino defender el socialismo - combatir por la libertad, esto no significa otra cosa que el tener ideas se hace para ellos casi imposible, mientras que es tarea fácil y atractiva la de defender los derechos del hombre. Cuando los individuos sienten confusamente su falta de aptitudes para el destino primario y efectivo en que cayeron, buscan otro oficio vago y caprichoso para fingirse una compensación. A este respecto puede repetirse con Ortega y Gasset:

Uno ha visto tantos hombres que, de buena fe, necesitan, además de su destino real, dar a su vida una especie de segundo piso imaginario donde poder representar una comedia de grandes actitudes y hacer cuadros plásticos de virtud, de ascetismo, de sacrificio.

Y menos mal cuando tales escritores se reducen a defender la libertad y proclamar la lucha de clases, porque en tal caso les asiste, en una u otra forma, la conciencia de los pueblos; y siempre es preferible, a la verdad desnuda, escueta, la ver- 
dad hermoseada y atrayente. Pero esta gimnasia de los ideales traspasa todo límite. Por medio de ella se llega a un laberinto de ideas, persistiendo sólo el propósito mesiánico, vago, confuso, incomprensible en un estudiante, imperdonable en un pensador.

La política, que es siempre tendencia a soluciones prácticas y viables, se desprestigia, parece insuficiente a los ojos de la masa, junto a ese aluvión idealista, en el que cada principio aspira a superar a los demás, por mediode lo cual se llega a los más absurdos retorcimientos. Este preciosismo de las actitudes espirituales alcanza hoy términos pavorosos; las multitudes oyen hablar de Vivekananda, de Ramakrisna, de los yogas, de todas esas concepciones orientales, incompatibles con la idiosincrasia y la cultura europeas y que no significan más que la nebulosa en que se encierran los que han decaído, los que ya no saben crear, los que están realmente incapacitados para traducir el secreto del siglo en que vivimos. Estos no hacen, de este modo, más que hurtar el cuerpo a las preocupaciones y adoptar actitudes ridículas. Su conducta equivale a la de las aristocracias inconscientes que no sintieron la proximidad de las revoluciones y que contribuyeron con sus elegancias y su despreocupación a precipitarlas y a justificar sus desmanes. Y como la de éstas, la actitud de aquéllos puede constituir un índice del fin que se acerca, del término que alcanza un período histórico, según la agudísima observación de El Espectador:

Este carácter ficticio de alto juego o sublime deporte que suelen poseer los ideales, se va revelando poco a poco conforme la época avanza hacia su consunción. Así acaeció con el ideal caballeresco. Nunca se extremó tanto el desplante, la retórica y el escenario de la caballería como en el siglo XV y fines del XVI, precisamente cuando la realidad social estaba ya constituida en otra torma incompatible con aquellas gesticulaciones.

$Y$ aun cuando en rigor no se considerara esta literatura como un signo de la decadencia de Occidente, bien puede conducir a ella; pues el mundo no logrará salir del caos en que se debate mientras no cese este diluvio de profetas mesiánicos, en tanto no regrese cada cual a lo suyo. - F. O R T Ú Z A R V I A L. 